\title{
EL IMAGINARIO POÉTICO EN UN RÍO, UN AMOR, DE LUIS CERNUDA
}

\section{Esperanza R odríguez Ortiz}

RESU MEN: Se analiza en este artículo uno de los temas fundamentales de la obra poética de Luis Cernuda: Ia construcción del imaginario simbólico de su etapa surrealista, en un libro fundamental para entender el pathosromántico del poeta como U n río un amor. Siguiendo la pauta de los ensayos de Gaston Bachelard, y su método de interpretación simbólica, que podríamos definir como una poética de lo imaginario, hemos recorrido el devenir espiritual de Luis Cernuda en una etapa apasionante: su iniciación vital y poética, que el influjo surrealista convierte en una voz de intemporal originalidad.

RÉSU MÉ: On analyse dans cet article un des thèmes fondamentaux de l'oeuvre poétique de Luis Cernuda: la construction de l'imaginaire symbolique de son étape surréaliste, dans un livre fondamental pour comprendre le "pathos" romantique du poète, comme dans Un río un amor. Si I'on suit la règle des essais de $G$ aston Bachelard, et sa méthode d'interprétation symbolique, que I'on pour rait definir comme une "poétique " de l'imaginaire nous avons parcouru le "devenir" spirituel de Luis Cernuda dans une étape passionnante: son initiation vitale et poétique, que l'influence surrealiste convertit en une voix d'originalité intemporelle.

PALABRAS CLAVE: soledad, angustia, noche, desolación, frío, gris, vacío, libertad.

MOTS CLEFS: solitude, angoisse, nuit, désolation, froid, gris, vide, liberté.

Un Río, un Amor es el primer libro importante de L uis Cernuda, casi me atrevería a decir que es su primer libro porque en él despierta, sale a la luz o emerge el poeta oculto que ha estudiado Rafael A rgullol en su ensayo interpretativo del Romanticismo, El héroe y el únicoํ. Es cierto que Cernuda ha publicado ya un

1. A rgullol, R. El héroe y el único, Barcelona, Destino, 1990. El poeta oculto representa en el argumento de A rgullol al poeta espontáneo, una especie de dios-niño para el que los espacios oníricos y espacios reales se confunden. A Igo semejante le ocurre a Cernuda en este libro, si además tenemos en cuenta su lectura como el descenso al propio infierno, el viaje dionisiaco trascrito al lenguaje del sueño como camino de exploración del yo inconsciente, así como la caracterización de un 
librito de poemas, Perfil del aire, cuya acogida le ha parecido fríaª , y que ese primer desencanto abre una herida profunda en su percepción del medio literario: no dejará de dolerle lo que su sensibilidad acusa como una ignorancia, un desconocimiento de su mundo, incluso como mala fe en una lectura que atribuye a sus poemas el brillo de la estética guilleniana antes que a un universo propio, tan presente por otro lado, y que pugna ya por cobrar forma y expresión. Cernuda se retirará así a sus cuarteles de invierno (y siempre fueron frías sus moradas), para componer un artificio poético interesante como ejercicio de estilo y también como configuración de su atmósfera poética, E gloga, Elegía y 0 da, emocionados homenajes a Garcilaso y Fray Luis, donde Cernuda despliega no sólo una sensibilidad métrica notable sino una mise en scène de su mirada narcisista - mirada que enmarcaban ya los breves poemas de Perfil del aire-, en un idílico locus amoenus, pero irremediablemente condenada a la expulsión, como ocurre con cualquier refugio paradisíaco.

Es por ello que la lectura de Un Río, un Amor invita a una interpretación iniciática del viaje de descenso a las profundidades del yo, y no sólo por la brusca transformación del utillaje poético que va a desplegar el poeta en la composición de estos nuevos poemas, sino por la esencia dionisiaca que busca comunicar de manera consciente. No por otra razón me he referido al emerger del poeta oculto, porque, en efecto, en este libro aflora ya de manera irreversible la imagen del

arquetipo romántico como es el sonámbulo, bien estudiado por A rgullol. Cernuda, en efecto, dibuja en los primeros poemas de U n Río, un Amor la figuración de un ser náufrago que deambula entre el sueño y la realidad, y que representa la necesidad de emerger como voz poética; así nos dice A rgullol: "L a potencia oculta, el poeta oculto es el mismo Yo liberado de las cadenas de la racionalidad y, consecuentemente, crecido gigantescamente hacia los horizontes imposibles del cielo y el infierno. A partir de esta conclusión, para el romántico se abre la posibilidad de abrir una brecha ontológica en el limitado espacio de la racionalidad" Pág. 396. No en vano la poesía de Cernuda busca en este libro la expresión de la irracionalidad por medio de un discurso tomado de la influencia surrealista que libera la imaginación, y desde luego abre esa brecha ontológica de que nos habla A rgullol. Cernuda confirma, además, su adscripción romántica en estos poemas, encarnando definitivamente la figura del poeta como héroe y desde luego como único.

2. Cernuda comienza a escribir P erfil del Aire en 1924 y lo publica en Málaga en 1927; de la acogida del libro escribe en "Historial de un libro": "Poco después cayeron sobre mí, una tras otra, las reseñas acerca de Perfil del Aire: todas atacaban el libro. Pero lo que más me dolió fueron las cortas líneas evasivas con las cuales Salinas me acusó recibo desde M adrid. L as críticas giraban, más o menos, sobre dos puntos: uno, que yo no era "nuevo" o, como al gunos decían entonces, con dos términos ridículos que me excuso por repetir ahora, "novimorfo" ni "porvenirista"; el otro era el de imitar a Guillén." Prosa Completa, B arral editores, B arcelona, 1975, pág. 903. Olvida Cernuda la reseña de B ergamín, que resal taba la sensibilidad del joven poeta. V éase Litoral N úmeros 79-8081 , págs. 181 y ss. 
poeta, lo que más adelante, una vez alcanzada la madurez, habrá de transformarse en un complejo mito romántico -Cernuda es nuestro último gran poeta de estirpe romántica-, pero que ahora germina como la figura de un ser cuya identidad se reconoce en el espejo de la poesía; identidad perfilada desde una interpretación prometeica, heroica, salvadora, y desde luego enfrentada al mundo vulgar y esclavizado de los hombres ${ }^{3}$. Pero habrá tiempo de volver sobre esta cuestión más delante.

Tiene Cernuda 27 años cuando comienza a escribir los primeros poemas de Un Río, un Amor, y naturalmente en su vida han ocurrido acontecimientos decisivos para su proceso de formación: no sólo ha publicado un libro y ha decidido que su universo íntimo se llama poesía ${ }^{4}$, también ha perdido a sus padres (su padre muere en 1920 y su madre en 1928) y por vez primera y definitiva ha abandonado Sevilla. Sin embargo, y a pesar de las ansias embriagadoras de libertad, Luis Cernuda es todavía un adolescente, ciertamente tardío para su edad. No sabemos qué significado tuvo el peso de la orfandad para sus soledades, porque nunca lo manifestó por escrito, aunque nos recuerde la visión familiar en un muy agrio poema "La familia" de Como quien espera el alba, donde retrata la condición familiar en una atmósfera opresiva y dolorosa; pero, incluso desde el silencio en torno a esta cuestión, no resulta difícil imaginar que debió al bergar sentimientos contradictorios, pues de un lado despegaba de un mundo cerrado, enrarecido, que limitaba en todos sus flancos con una atmósfera íntima de ensoñación narcisista, donde el perfil del aire que evoca en su primer libro comenzaba a hacerse denso y con seguridad irrespirable, pero de otro lado, se abría a un espacio desconocido, mucho más hostil, donde empieza a sentirse extraño, como un presentimiento de su destino de desterrado. Porque los primeros poemas de U n Río, un Amor no son de ninguna manera un canto de liberación sino más bien todo lo contrario: componen un escenario de cerrada soledad, de intenso frío y de anhelos lejanos, ensoñación de unos imprecisos paraísos, como siempre perdidos. El caso es que

3. Figura que también ha estudiado Rafael Argullol en la poesía de Keats y en la obra de Nietzsche, I dem. Págs. 157 y ss. La proyección de Cernuda en el mito del poeta tiene, en efecto, un fuerte cuño romántico, pues su sueño de identidad alimenta la rebeldía y convierte al poeta en un ser diferente cada vez más alejado de los hombres que no saben soñar. U na identidad, en el caso de Cenuda reforzada además por su natural eza sexual, que deviene en la de un ser doliente, condenado a la soledad, pero elegido para una misión superior, pues es voz de los hombres mudos, como escribirá en Invocaciones, antorcha de luz en un mundo oscuro

4. Escribe en Historial de un libro: "Ya entrado en la edad madura, volviendo sobre mi niñez y adolescencia, percibí cómo todo en ellas me había preparado para la poesía y encaminado a ella". 0 pus cit. pág. 898. 
Cernuda Ilega a Toulouse en 1929 como lector de español ${ }^{5}$, un puesto auspiciado por J aime Salinas, profesor suyo de Facultad, aunque le haya dolido, como sabemos, lo que él considera indiferencia evasiva ante su primera publicación. Viaja enseguida a París y la atmósfera que todavía se percibe de la conmoción que ha supuesto el eclosionar vanguardista, le fascina y es el impulso que abre la compuerta para dar rienda suelta a una necesidad de decir del poeta, de expresarse, que definitivamente toma el camino de la estética de la modernidad. La influencia surrealista que Cernuda hará suya aunque siempre matizada (de ninguna manera escribirá "automáticamente", aunque sí jugará a la técnica del collage), suponen, en este sentido, una transformación extraordinaria de su voz poética. L os poemas nacen con tremenda espontaneidad, casi atropellándose unos a otros,

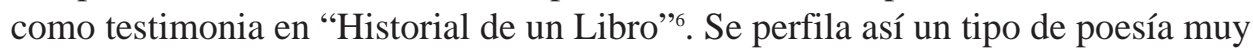
diferente a la de los libros anteriores, que se inscribe en diferentes estímulos de inspiración pero también en la necesidad de liberar su mundo interior, de entrar, pues, no sólo en el ámbito de la modernidad estética sino de incorporar la libertad vital y de reafirmación de lo que ya percibe como diferencia (y que tiene en la homosexualidad su primer fundamento). U na diferencia que el poeta comienza a descubrir como la de un ser único y perdido en un mundo en el que casi todo le es ajeno. Para comunicar ese universo recién descubierto que le cerca y a la vez le empuja a romper cadenas, Cernuda va a desvelar una fuerza simbólica desconocida hasta ahora en su creación poética. Emerge el poeta, ciertamente, casi de manera salvaje, y toda la imaginería que parecía oculta al fondo de las aguas de la fuente de $\mathrm{N}$ arciso se desencadena ahora en la fluencia de ese río impetuoso en

5. A pesar de lo que le había dolido la escueta respuesta de Salinas, profesor suyo de Literatura en la Facultad de Derecho de Sevilla, Cernuda acepta sus gestiones para proporcionarle un puesto de lecteur d'espagnol en la universidad de Toulouse: "Económicamente resultaba bien poca cosa, pero era una salida primera al mundo y la ocasión para usar una lengua que conocía en teoría pero no en la práctica". Y confiesa a continuación: "Recibido el nombramiento de lector, al despedirme de Salinas un atardecer, con frío invernal ya cercano, la estufa y la luz encendidas en su casa, me atacó insidiosamente la sensación de algo que yo no tenía, un hogar, hacia el cual, y hacia lo que representa, siempre he experimentado menos atracción que repulsión" I dem, pág. 908. Palabras que evidencian los sentimientos contradictorios de Cernuda, aunque elija su soledad frente a cualquier cobijo, y menos aún familiar.

6. "De regreso en Toulouse, un día, al escribir el poema "Remordimiento en traje de noche", encontré de pronto camino y forma par expresar en poesía cierta parte de aquello que no había dicho hasta entonces. Inactivo prácticamente desde el año anterior, uno tras otro, surgieron los tres poemas primero de la serie que luego llamaría "Un Río, un A mor", dictados por un impulso similar al que animaba a los surrealistas (...): una corriente espiritual en la juventud de una época, ante la cual yo no pude, ni quise, permanecer indiferente" Idem, pág. 909. 
ocasiones, detenido y claustrofóbico en otras, pero río al cabo, donde buscará perdidamente el amor, todavía sin nombre.

He escrito que la lectura de un Río, un Amor puede, y creo que debe efectuarse desde una perspectiva iniciática. Lo creo así porque se trata de la primera salida del poeta al mundo, de su primer choque con la realidad, que ahora comienza a ser definida y padecida, ya no sólo como una percepción más o menos perdida en lejanía, sino como una abierta confrontación al mundo del deseo. La orfandad, el al ejamiento de Sevilla, la vida en Toulouse en invierno y el impulso que supone el viaje a París impregnan el libro de soledad y desarraigo, de angustia y ansias de libertad, de una vaga nostalgia por la inocencia perdida, concebida como luz, y de un deseo de escapar del sueño hipnótico de una adolescencia que ha resultado demasiado prolongada y que amenaza con asfixiar al poeta en un narcisismo que ahora comienza a desvelarse como inane. Debe salir al mundo, aunque la imagen que nos transmite su mirada sea desoladora. Pero toda iniciación, decía, es un viaje de conocimiento, de descenso a la propia interioridad, y es este sentido dantesco el que Cernuda recorre en este libro, mientras la voz poética despliega un torrente de representaciones del estado interno del poeta que configura el paisaje del libro en una composición de carácter urbano, donde el protagonista vaga perdido, envuel to en gradaciones de colores fríos que oscilan entre las tonalidades del gris ceniza y el acero, atmósfera que sirve al poeta para dar cuenta, alegóricamente, del propio extrañamiento. Q uizá sea ese aspecto iniciático, ligado, naturalmente, al influjo de las asociaciones simbólicas del descubrimiento de la estética surrealista, lo que impregna a Un Río, un Amor de una textura y una coloración claramente oníricas. Bien es verdad que el descenso a la propia interioridad inevitablemente ha de tejerse con el hilo de los sueños - F reud no ha perdido vigencia desde esta perspectiva- y Cernuda, un especialista en la materia pues ha demostrado en sus primeros libros ser, en efecto, un morador de entresueños, registra ahora su interioridad abismada en la exploración de ese paisaje de sueño y pesadilla, cuya dimensión trágica desnuda un infierno friolento de pérdida y amarga soledad.

La realidad que el poeta advierte como hostil, extrañándole de sí mismo, se proyecta en imágenes nocturnas, entre sombras desrealizadas, donde se olfatea el miedo, aunque éste permanezca invisible, o donde las luces carecen de vida. Un mundo visionario, extranjero, Ileno de tropismos uranianos, en los que el protagonista fantasmagórico de los primeros poemas de Un Río, un Amor se perfila como un soñador de la noche: vaga, pues, insomne por el fondo de corrientes submarinas, ahogado y gris en medio de un denso silencio, porque la tierra y los hombres, desconocidos seres ajenos, están muertos. M uerto en pie también este anó- 
nimo durmiente que se desvela, enredado todavía entre las lianas que Hipnos - extraña Circe- ha tejido durante el sueño adolescente, y que le ha despoblado de realidades, por ello siente el vacío y, muy pronto, la caída:

Un hombre gris avanza por la calle de niebla;

No lo sospecha nadie. Es un cuerpo vacío;

Vacío como pampa, como mar, como viento,

Desiertos tan amargos bajo un cielo implacable. (R. y D. Pág. 83) ${ }^{7}$

El río de la vida, que es también un río de olvido, arrastra al poeta en un mäelstrom de sombras fatigadas, le empuja violentamente a este mundo del color de una alucinación, en medio de espacios inhóspitos. Leemos de este modo en los primeros poemas de Un Río, un Amor el terrible periplo de un hombre perdido en la percepción del propio infierno: es el mendigo de realidades envuel to en la espesa niebla de un paisaje cuya realidad, si fuera a tocarse, se disolvería en sombra, y donde sólo los deseos sueñan vagamente todavía una lejanía de luces. M emoria de apariencias. Ese cuerpo vacío de "Remordimiento en traje de noche", ha perdido las alas, no tiene ya fuerza, como el torpe albatros de los versos de Baudelaire, burla de marineros, caído en tierra, al que alas de gigante le impiden andar. Sordo el mundo, el poeta se enfrenta al tiempo perdido, que azota como un remordimiento. Y este poeta, aislado en la sombra, busca la objetivación de sí mismo alejándose en imágenes ${ }^{8}$, como ha escrito Luis Felipe Vivanco, pues imágenes, y además visionarias, son las que desgrana en los poemas "Cuerpo en pena", "Como el viento", "Decidme anoche" e incluso en "Oscuridad completa". L a imaginería poética que despliega Cernuda -y hay que añadir que con un dominio rítmico muy afianzado, pues el poeta mide bien los versos y le gustan los juegos anafóricos, y que ya podíamos apreciar como algo más que ejercicios de estilo en Perfil del Aire y E gloga, Elegía y 0 da- se compone en gran medida de un imaginario simbólico en el que el agua, como elemento primordial, ocupa un lugar privilegiado junto a las imágenes en que se proyecta el deseo en anhelo de luz.

7. Utilizo la edición a cargo de Derek Harris Y L uis M aristany Poesía Completa, de Luis Cernuda, Barral Editores, B arcelona, 1977, 2ª edición revisada. En adelante las páginas citadas tendrán como referencia esta edición.

8. Luis Felipe Vivanco, en su ensayo ""Luis Cernuda en su palabra vegetal indolente" en Introducción a la poesía española contemporánea, M adrid, Guadarrama, 1957, pág. 305, donde habla de una primera etapa en la poesía de Cernuda en la que el poeta se aleja en imágenes, para luego objetivarse en figuras, ya en su poesía de madurez. De otro lado, también podemos encuadrar las imágenes simbólicas de Un Río, un Amor en lo que Carlos B ousoño ha denominado "símbolos heterogéneos" y que a menudo, en este libro, aparecen encadenados, B ousoño, C., El irracionalismo poético (El símbolo), M adrid, Gredos, 1977, véanse las págs. 127-128. 
G. B achelard ha estudiado las imágenes del agua en su libro El agua y los sueños ${ }^{9}$, y me parece de especial interés su inteligente lectura de las aguas profundas, analizando el mundo simbólico de Edgar Allan Poe, o su análisis del narcisismo, imprescindible para la comprensión del universo cernudiano, sin olvidar la lectura de las aguas claras, simbolización del deseo en el Cernuda de la madurez. Pues bien, si, según advierte Bachelard, "Ias imágenes tienen (...) una materia"10 como fuerzas imaginantes que ahondan en el conocimiento del ser y la simbología de los elementos primigenios, y deben, por tanto, asociarse a las cosmologías intuitivas, lo que hallamos al interpretar la figuración acuática en estos primeros poemas del libro cernudiano, es una cadena fenomenológica en la que la imaginación poética, en efecto, se revela como materia. Visual, como corresponde a la poesía del siglo XX, sobre todo a la que absorbe la influencia de las técnicas vanguardistas y el ascendiente determinante del cine. Las imágenes visionarias de U n Río, un Amor plasman la materialidad poética de un mundo submarino, emanación del inconsciente, de quien no encuentra su espacio terrestre, y el aislamiento, la inmensa oquedad de un ser doliente atrapado en el miasma de unas aguas que se revelan como profundas ${ }^{11}$ desde el momento en que el protagonista de los poemas deviene en náufrago o ahogado perdido en el laberinto, como en estos versos:

9. G. B achelard ofrece en sus análisis una interpretación de corte psicoanalítico centrada en el estudio de los símbolos, para desvelar justamente la figuración de mundo oníricos; su poética de lo imaginario indaga los universos simbólicos de los elementos naturales, tierra, aire, fuego y agua, relacionándolos con el mundo del sueño. No sólo resulta interesante el libro citado, El agua y los sueños. Ensayo sobre la imaginación de la materia, Fondo de Cultura Económica, M éxico, 1994, tercera reimpresión de la primera edición en español, sino El aire y los sueños. Ensayos sobre la imaginación del movimiento, Fondo de Cultura Económica, M éxico, 1993, sexta reimpresión de la primera edición en español, o La poética del espacio, Fondo de Cultura Económica, M éxico 1998, segunda reimpresión de la segunda edición en español. La simbolización y el imaginario poético de Un Río, un A mor puede interpretarse perfectamente a la luz de los ensayos de Bachelard, pues a través de ellos descubrimos a Cernuda como poeta del agua y del aire: Ios elementos acuáticos asociados eminentemente a su carácter narcisista y el aire a su evidente platonismo de tendencia órfica. Cernuda descubre tardíamente la tierra (en Invocaciones) y el fuego aparece ligado siempre a la expresión de la luz.

10. B achelard, G. El agua y los sueños, pág. 10.

11. V éase el ensayo de B achelard sobre las aguas profundas en E. Allan Poe, Ibidem, págs. 74 y sS. 
Lentamente el ahogado recorre sus dominios

Donde el silencio quita su apariencia a la vida,

Transparentes Ilanuras inmóviles le ofrecen

Á rboles sin colores y pájaros callados.

$(\ldots)$

Su insomnio maquinal el ahogado pasea.

El silencio impasible sonríe en sus oídos.

Inestable vacío sin alba ni crepúsculo,

M onótona tristeza, emoción en ruinas. (R. y D. Págs. 86 y 87)

0 en los que interroga al vacío, envuelto en la niebla, como en "Decidme anoche":

Fantasma que desfila prisionero de nadie,

Falto de voz, de manos, apariencia sin vida,

Como llanto impotente por las ramas ahogado

0 repentina fuga de estrellas en un muro. (R. y D. Pág. 91)

A guas insondables, reflejo invertido de un cielo que ya no ilumina, soledad y niebla para el río de Ofelia que arrastra la imposibilidad de comunicación del poeta. $Y$ es aquí donde debemos hacer memoria obligatoriamente y recordar que el Cernuda de los primeros libros bosqueja en sus versos a un adolescente inclinado sobre la fuente: es Narciso ensoñando en el espejo del deseo la propia indolencia. El reflejo en las aguas quietas era entonces el de un rostro puro, ya se encontrara en su cuarto frente al papel en blanco -imagen muy mallarmeliana, como muchas de las que hallamos en P erfil del aire-, o en una naturaleza cuyo ensueño es paradisíaco. Son las aguas de una fuente, imagen de eternidad, donde, como en el cuadro de Cranach el Viejo, La ninfa de la fuente, que se conserva en el M useo Thyssen-B ornemisza, donde nada perturba la transparencia quieta. Pero en U n Río, un Amor la perspectiva ha cambiado completamente: quien escribe estos poemas, el poeta emergente, el poeta escondido, ya no está protegido por las paredes de su ámbito cerrado, ni encuentra tampoco en cuanto le rodea la dimensión del jardín arcádico: ha sido arrojado a un mundo de sombras en el que no encuentra sino despojos de la antigua luz. ¿Dónde hallar, pues, el reflejo? U na medida que no sea la de la propia asfixia en un mundo sordo. El reflejo que cubre los primeros poemas de Un Río, un Amor tiene la palidez de la muerte, la opacidad de un mundo fantasma. Es verdad que el narcisismo paralizante de los primeros libros estrangulaba una irrefrenable necesidad de crecimiento, pero en este nuevo libro el poeta no buscará tanto la abolición del reflejo, puesto que le es necesario para reconocerse, como la trascendencia de aquel narcisismo primitivo; quiere escapar, por tanto, a sus efectos más letales, si anhela una figura apolínea tras el reflejo de sí mismo, o 
mejor, de su deseo, pero ya en el mundo abierto de los otros. N os encontramos ante una imperiosa necesidad de trasponer la barrera, de romper el vidrio que separa y aísla; de cruzar, en suma, el muro del jardín cerrado, y escapar así de un laberinto de espejos que le atrapan y esterilizan como en una mampara de cristal infranqueable. Y soñará enseguida con el reflejo del amor, evidente proyección neoplatónica, como única salvación posible. Del narcisismo individual en el que atónito el poeta descubre la belleza, trascendemos de esta manera a una búsqueda del narcisismo cósmico ${ }^{12}$ : la fuente deviene en río, y es en esas aguas frías de la pérdida donde el poeta busca el necesario reflejo que le libere del tormento, la mirada, la forma del otro. Con esta proyección el narcisismo primario que se transforma ampliando su objeto de deseo, el poeta se abre al mundo.

Sin embargo, en el amplio recorrido del libro todavía no aparece el vivo dibujo de ese rostro que le redima de sus soledades, aunque en los últimos poemas parezca centrarse en la visión de cuerpos presentidos, entrevistos o imaginados tal vez, pero todavía de forma inconcreta, todavía sin nombre; por ello la realidad le resulta tan lejana a su deseo de calor humano, que percibe envuelta en esos elementos impasibles donde el paisaje urbano cobra, como hemos visto, la forma de un universo sonámbulo, donde las palabras son apenas balbuceos. Como una transposición de las pinturas de Delvaux, el universo cernudiano se viste de imágenes fantasmagóricas, donde la presencia de la muerte es una constante. Cortejos de fantasmas con cadenas colgando de las manos. Extrañeza y abismo donde habitan los hombres dormidos, averno que atraviesa el poeta en su viaje interior encontrando a su paso "glaciares del infierno", "fantasmas grises de piedra nebulosa" o "estanques disecados". Son imágenes que obligan al lector a navegar en un río que, no tan paradójicamente -hay desiertos calcinados en el libro-, tiene puntos de conexión con una tierra que adivinamos baldía ${ }^{13}$ : la esterilidad de las

12. Resultan clarificadoras las páginas de B achelard dedicadas al análisis de la simbología de las aguas claras y primaverales, donde el protagonista es Narciso como imagen de la inocencia, pero se trata de una visión que de no abrirse siempre resulta neurotizante, por ello ha de convertirse en espejo del mundo, reflejo de una belleza que integre al otro, germen evidente de un claro pancalismo. Son muy interesantes también sus reflexiones sobre la filosofía de Schopenhauer y la voluntad de representación del propio mundo en las imágenes de la poesía, como visión activa, de manera que la contemplación se nos antoja como una forma de voluntad, de voluntad, claro es, de belleza. $\checkmark$ éanse págs. 36 y ss.

13. Hacía muy pocos años que T. S. Eliot había publicado The Waste Land, pero no creo que Cernuda conociera el poema en las fechas de redacción de U n Río, un Amor: está deslumbrado por la poesía francesa y la lectura de $\mathrm{Ch}$. B audelaire y, sobre todo, de A. Gide, quien tiene una influencia definitiva en la conformación de su identidad estética y sexual. El encuentro con la poesía de 
aguas profundas es la prolongación del reino de Hipnos que perpetúa todavía la inmovilidad de la clausura narcisista. La corporeidad como forma e incluso como afirmación ya dije que todavía está ausente, y Cernuda atraviesa su Estigia ${ }^{14}$ con un aire cansado, como quien lleva a cuestas un enorme peso, y mientras busca la luz halla únicamente niebla. R esuena así la conciencia de la libertad en una vasta visión de la muerte.

Que asociemos casi con inmediatez este universo plástico a la expulsión del paraíso o a la pérdida de la inocencia, si el protagonista de los versos ha perdido las alas en el envite, es consecuencia directa de esta percepción de hostilidad, de silencio, y es obvio que de una clara vivencia del mundo real como naufragio, no en vano escribirá:

Bajo la noche el mundo silencioso naufraga

B ajo la noche rostros fijos, muertos, se pierden.

Sólo esas sombras blancas, oh blancas, sí, tan blancas,

La luz también da sombras, pero sombras azules. (R. y D. Pág. 85)

Perdido en el mundo de esta realidad infernal, vaga el poeta escalofriado, ensoñando luces lejanas, sombras blancas de abolida inocencia; o trata de escapar, en arrebato romántico, vestido de viento, identificado ahora con su furia, tocando vidrios en vano, sollozante, y abandonado, finalmente, en las esquinas. Como más adelante, buscará la misma proyección en el agua, alejándose en la imagen del mar que, errante, tratará de encontrar el calor de una mirada, para regresar, de nuevo, abatido y turbio, refugiándose en la amargura de un Ilanto infecundo. El viento y el mar, sin duda, juegan ya un papel claramente iconográfico como fetiches románticos. A sí pues, comprobamos que los poemas de U n Río, un Amor narran, en imá-

Eliot en la madurez de Cernuda y su conocimiento de la poesía inglesa imprimirán un tono meditativo a sus poemas a partir de Como quien espera el alba, ya visible en ese libro bellísimo que empieza a escribir al estallar la Guerra Civil, Las nubes.

14. De nuevo podemos recurrir a la interpretación de Bachelard cuando nos habla del complejo de Caronte, opus cit. Págs. 111 y ss, donde interpreta el significado del descenso al río de los infiernos como un espectral torrente donde el agua simboliza la tumba del fuego, la tumba de los hombres, el horror del ahogado. No es difícil asociar esta interpretación a la lectura de U n Río, un Amor. 
genes poéticas de enorme fuerza sugestiva, la epopeya de un desolador fracaso, de una brutal impotencia. Y Cernuda empieza a identificar, como anuncié, ese profundo hundimiento en el propio abismo con la imagen, que en el libro siguiente se desvelará miltoniana, del ángel caído, pues la mirada que va posando sobre la realidad tiene una dimensión atroz de espejo invertido. La sombra cubre al poeta, él mismo la arrastra ocupando todo el espacio donde hasta el tiempo -insomne- ha perdido significación, como escribe en "Destierro":

Le abandona la noche y la aurora lo encuentra,

Tras sus huellas la sombra tenazmente. (R. y D. Pág. 88)

Es por eso que añora las luces. Y tienen, desde luego, un ascendiente poético surrealista: se inspira Cernuda en la parte más atractiva del mundo que ha empezado a explorar: el cinematógrafo, la recién descubierta música del jazz... ${ }^{15}$, y muy pronto esas sugestiones entresoñadas se convierten en evocaciones de un mundo de añoranza paradisíaca, muy vago, es cierto, con un aire de lejanía, casi de escenificación cinematográfica, donde las mismas palabras insinúan reminiscencias o sueños. Porque no se trata de un mundo que remita exclusivamente al pasado sino que se proyecta sobre un futuro que se espera conquistar. Pero este universo, que indudablemente permite al poeta respirar en medio de su espectral deambular entre sombras, hunde sus raíces, como he apuntado, en una evidente concepción neoplatónica afincada en el mundo del deseo. Un deseo puro, porque la abundancia de sombras blancas, el destino concebido como luz y transparencia (el extranjero, nos dice, que ahora deambula por ese mundo de dimensiones oníricas "vino como luz"), combate la opacidad de lo real. Los sueños de las sombras blancas son, en cualquier caso, espejismos del deseo, pero en ese refugio, aunque precario, el poeta puede todavía interrogarse y dar cuerpo a una voz menos desasosegante. Si extrañado vaga entre las sombras de un castillo de hielo, su deseo, su sueño de despertar hacia otros mundos prometidos o añorados, bien sea desde una perspectiva teñida de una imprecisa nostalgia o como anhelo de un mundo futuro presentido, lo cierto es que van a devenir también en fracaso. Le ocurre a Cernuda, en su viaje interior, en su descenso a los infiernos, como al mismo Orfeo al posar su mirada sobre Eurídice, que al volverse para comprobar

15. “Dado mi gusto por los aires de J azz, recorría catálogos de discos y, a veces, un título me sugería posibilidades poéticas, como éste I want to be alone in the South, del cual salió el poemita segundo de la colección susodicha y que algunos, erróneamente, interpretaron como expresión nostál gica de A ndal ucía. En París había visto la primera película sonora, cuyo título, "Sombras blancas en los mares del sur", también me dio ocasión para el tercer poema de la colección". Cernuda, L., O pus cit. Pág. 909. 
su realidad, el sueño se deshace. 0 se transforma en la mirada petrificada de la mujer de Lot. La búsqueda de otros mundos se quiebra y resulta, finalmente, decepcionante, es apariencia acaso:

No sé por qué, si la luz entra, Los hombres andan bien dormidos, Recogiendo la vida su apariencia J oven de nuevo, bella entre sonrisas. (R. Y D. Pág. 93)

Ningún cuerpo se allega a la presencia del poeta para hacerle cobrar realidad, y así termina perdiéndose en un "sueño de piedra". Pero si es cierto, como escribió M aría Zambrano, que no hay ningún infierno que no sea la entraña de algún ciel $0^{16}$, Cernuda explorará muy pronto el franqueo hacia esa apertura al paraíso en la luz del amor, la única redención posible, preexistente, que le devuelva la iluminación que ahora sueña en las sugestiones del sur, en la evocación de "Nevada", donde la insinuación de la misma palabra se abre a la cadena simbólica de imágenes, donde todavía los paisajes permanecen "dormidos en el aire", y el desierto, aunque sea desierto "Ilora mientras canta". También se fija en universos suspendidos, permanentemente esbozados, en los que encontramos una prefiguración de aquellas escul turas inacabadas de M iguel Á ngel, en las que el Cernuda de la madurez verterá su anhelo de pureza perdida convirtiéndolas en símbolo de una inocencia aún no nacida, fruto de la impresión de caída que se advierte ya en este libro.

El lector se siente aliviado al descansar en estas imágenes alusivas a proyecciones soñadas frente al cuerpo en pena que se arrastra por el aciago laberinto de espejos, donde quizá halla "un golpe de luz, la memoria del aire", pero desde la lividez mortal de la pérdida, y donde toda su visión se estanca en el tormento de una desolación que le aísla, un muerto entre los muertos en tierra estéril, donde el poeta habla, canta a solas:

Sí, la tierra está sola; a solas canta, habla,

Con una voz tan débil que no alcanza el cielo;

Canta risas o plumas atravesando el espacio

$B$ ajo sol calcinante reflejado en la arena.

Es íntima esa voz, sólo para ella misma;

A I exterior la sombra presta asilo inseguro.

Un grito acaso pasa disfrazado de luces,

Luchando vanamente contra el miedo y el frío.

(R. y D. Págs. 91-92)

16. Zambrano M. Claros del bosque, Seix Barral, Biblioteca de Bolsillo, Barcelona, 1986, pág. 140. 
M ientras el dolor ya muerto rompe perspectivas, sabemos que la pérdida de la inocencia convierte al poeta en un astro apagado, que llora impotente "por las ramas ahogado", donde la voz no logra alcanzar al cielo. El imaginario de la caída, la simbología de la expulsión del paraíso se concentra -como antes la simbolización del descenso al propio infierno en las aguas-, en elementos aéreos, que se expanden desde la creación de núcleos de significación, bien simbólicos o de textura plástica, pero que buscan siempre un efecto visualizador, una lectura de la imagen. Estas imágenes del aire tienen una importancia capital en la configuración del mundo poético cernudiano, no sólo porque Cernuda se haya revelado, desde sus primeros poemas como un poeta eminentemente aéreo (claro que sobre un fondo de agua: la imagen narcisista de la fuente siempre le acompaña), sino porque la definición de la figura del poeta, esa voz que ahora no alcanza el cielo, tiene como elemento primordial el aire, un elemento de fuerte connotación inmaterial. El aire es, en consecuencia, esencia de sueño, y así desfilan en los versos de Un Río, un Amor las imágenes de plumas, la impotencia de unos brazos que son nubes, las voces que buscan un aire navegable...: Ia inocencia perdida busca un trasunto en las sugerencias de vuelo. U niversos fluidos, no estancados como el fondo del río donde navega ahogado. Pasión de libertad: espacio también para el amor posible. Sin embargo, algo ha muerto dentro del poeta: si las nubes aparecen mutiladas es porque el ángel de las alas -de nuevo el albatros-, se sabe caído. B achelard identifica la imaginería aérea de plumas y alas a la blancura de la luz y a los sueños ingrávidos de imágenes ascensionales ${ }^{17}$, desmaterializadas como sublimación de la esfera celeste (y sólo tenemos que pensar en al gunos cua-

17. Bachelard, G., EI aire y los sueños, donde dice: "L a palabra ala, la pal abra nube, son enseguida pruebas de esta ambivalencia de lo real y de lo imaginario." Pág. 24. Y respecto al tema de la caída, también: "La caída profunda, la caída en las simas negras, la caída en el abismo, son casi fatalmente las caídas imaginarias en relación con una imaginación de las aguas (...): Semejantes descensos a los infiernos únicamente podrán ser descritos, desde el punto de vista de la imaginación poética..." Págs. 26-27, para concluir que la comprensión de la simbología de la caída ha de entenderse como una ascensión al revés. Es, en todo caso, la lectura más pertinente en el caso que nos ocupa: Ias imágenes ascensionales se asocian a la caída en la pérdida de una dimensión aérea que ahora se descubre mutilada o impotente, sin embargo la presencia de este elemento es una constante que se proyecta en la búsqueda de libertad. Recuérdense asimismo las evocaciones de las nubes en la delicada composición azoriniana de Castilla, "L as nubes", donde la asociación con la doctrina nitszcheana del eterno retorno toma cuerpo en esas nubes que pasan y sin embargo son siempre las mismas. El vuelo busca también en Cernuda una imagen de absoluto. 
dros de El Greco, en algún escorzo barroco). U na metafísica, por tanto, de la libertad, también leída en clave neoplatónica, donde el verbo escrito despierta ecos abstractos y donde desde luego los pensamientos y los sueños percuten como una refundición mítica de la realidad. Cernuda empezará a proyectar a partir de estas, todavía ligeras, imágenes aéreas la figura del ángel caído, que hacia el final del libro se viste de un aire vindicativo; un ángel que, paradójicamente, se revelará como redentor en su libro siguiente, Los placeres prohibidos, donde los pertrechos de una iconografía épica (la imagen de Perseo podríamos decir que se solidifica en el ángel) constituyen una fórmula de identidad liberadora para este poeta que acaba de atravesar las aguas terribles del Leteo. La ascensión vertical, sin duda, proviene de la caída como un impulso hacia lo alto, que deriva de un psiquismo de altura y que ya empieza a perfilarse con claridad en los poemas finales de Un Río, un Amor.

Pero no conviene adelantarse. Hay un momento de nítida inflexión en el libro, en el que una forma muy sutil de ironía se hace presente. Será un momento clave para comprender los movimientos del ritual iniciático. Cernuda regresa a $M$ adrid cuando ha compuesto ocho poemas. Es verano y, a pesar de sentirse en una "Oscuridad completa", trata ahora de distanciarse del propio infierno, que es una de las maneras más inteligentes de escapar de sus efectos letales. A hora bien, ese esfuerzo psicológico es fruto también de un evidente crecimiento poético y sobre todo de una lectura del propio narcisismo en clave positiva, diría que dinámica: un narcisismo que trasciende, como ya he señalado. La voz, incluso en sus soledades, es firme, como demuestran los poemas escritos, tan novedosos; así, con la vuelta a $\mathrm{M}$ adrid la perspectiva interna del libro empieza a transformarse. A coge, como un reflujo, la manifestación de la propia paradoja, su vivencia del enfrentamiento entre realidad y deseo en toda su trágica dimensión, pero también parece aceptarla, sabiendo de su imposible convergencia, apaciguando así su amargo desconcierto, para trazar una línea sinónima entre el arrebato de la libertad, siempre desencadenado desde la búsqueda del amor, y la desgarrada soledad que le cerca. A unque esa fuerza liberadora del amor tiene también la forma de los sueños, no supone sin embargo ya la trampa hipnótica de aquel narcisismo quieto en sus aguas, sino que empieza a conformar una estructura mítica en la que la propia imagen del poeta (bien sea, como dije, proyectada en una imagen angélica 0 épica), comienza a vestirse con ropajes de clara extracción prometeica. Cernuda va emergiendo así de su descenso al infierno, va encontrando elementos defensivos que protejan la fragilidad de su mundo y, sobre todo, va forjándose una identidad que le permita acceder a una realidad que él tiñe con el color de sus sueños. Emprende, pues, un camino taumatúrgico que tal vez proviene, en parte, de 
la creación de sus propios versos, de haber sacado a la luz esos terribles y fantasmales mundos submarinos a través de sus eficientes cadenas simbólicas.

¿Por qué no afirmar entonces que Cernuda acepta la muerte de la inocencia, el destierro, la caída? Cuando escribe "Estoy cansado" logra por fin ironizar en una mirada, contemplativa y a la vez alejada, su propio estado, consigue, pues, distanciarse, y en un caso como el suyo, de alguien que se toma a sí mismo tan en serio, es un paso importante. No sólo en el terreno de la psicología personal sino como inauguración de una técnica de estilo asimilada, claro es, de la corriente vanguardista:

Estar cansado tiene plumas.

Tiene plumas graciosas como un loro,

Plumas que desde luego nunca vuelan,

M as balbucean igual que loro (R. y D. Pág. 95)

J uan Ferraté analizó con agudeza este poema ${ }^{18}$ donde advierte que entre la carga negativa que se concentra en el texto (el tedio como repetición) puede extraerse un impulso positivo que es, justamente, la propia articulación irónica del poema. Es cierto que la aspiración al vuelo aparece caída en un estado de abulia, pero la misma técnica reiterativa en la sucesión de símbolos agiliza un discurso en el que el poeta resuelve su propia impotencia con una mirada que se aleja de sí mismo. Y seguramente esta inflexión en el tono resulta de alguna manera catártica, como después lo será el Ilanto, sobre todo si pensamos en el avanzar del proceso iniciático que encierra el libro: las alas están caídas y le aburre y le cansa al poeta la reiteración de ese sentimiento de pérdida, debe avanzar, por tanto, caminar hacia otro espacio. No en vano ha desvelado en el poema anterior, "Habitación de al lado", la presencia iconográfica de la muerte, invitación plástica a una visión nueva del antiguo universo dormido:

A través de una noche en pleno día

Vagamente he conocido a la muerte.

No la acompaña ningún lebrel;

Vive entre los estanques disecados

Fantasmas grises de piedra nebulosa.

¿Por qué soñando, al deslizarse con miedo,

Ese miedo imprevisto estremece al durmiente?

18. Ferraté, J, “Luis Cernuda y el poder de las palabras”, en Luis Cernuda, Taurus, Madrid, 1977, págs. 169 y ss. 


\section{M irad vencido olvido y miedo a tantas sombras blancas \\ Por las pálidas dunas de la vida, \\ No redonda ni azul, sino lunática, \\ Con sus blancas lagunas, con sus bosques \\ En donde el cazador si quiere da caza al terciopelo. \\ (R. y D. Pág. 94)}

Es hermosa esta figuración en la que el poeta encara el dibujo de la muerte, transformando la imaginería clásica en una visión vanguardista (el lebrel que aquí no existe, el cazador, los pájaros mudos, la mirada metálica), sin por ello abandonar un cierto eco romántico en la imagen de ese cazador que ya expresa su tedio en las "manos aburridas que cazan terciopelos o nubes descuidadas".

Y que ha aceptado la pérdida de la inocencia y, por tanto, un cambio de rumbo en su transcurrir vital, podemos apreciarlo con más precisión en "EI caso del pájaro asesinado", un poema en el que Cernuda, de nuevo distanciándose en la variación de la perspectiva que adopta el poema, el juego sobre la imposible resolución de un caso, como si fuera éste una ficha policial, vuelve sobre el tema del abandono del sueño o del deseo aéreo, ahora proyectado sobre el pájaro asesinado:

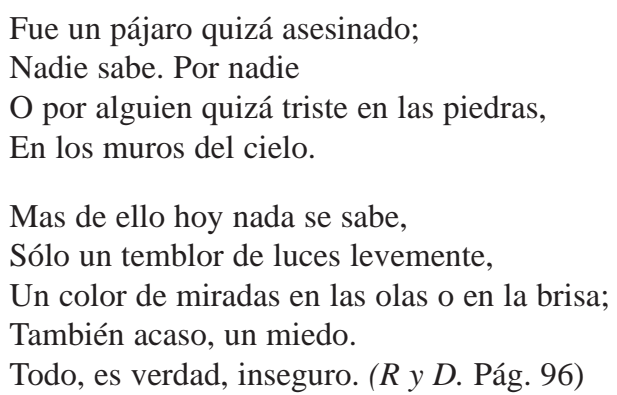

El poeta continúa habitando un espacio y un tiempo inciertos, y ahora lo corrobora, abiertamente, en la ausencia de la antigua imagen de la inocencia, expresamente ligada al simbolismo del pájaro. Pero el pájaro es también una voz que canta: la voz del poeta, en suma. Y será lo único que permanezca en medio de la pérdida. La poesía comienza a tomar una significación mítica, acompañada de la necesaria figura del Poeta. Si asociamos "Estoy cansado" con este bello poema que acabo de citar, notaremos enseguida cómo el protagonista de los versos reconoce implícitamente que su estado de ánimo, caído, sonámbulo, empieza a repetirse y que de esa nueva pulsión distanciadora nace otra voz, una voz que empezará muy pronto a buscarse en el combate, en la acción, porque, en efecto, éste es un mundo donde el sueño no es hermano de la acción, según dejó escrito Baudelaire. 
Esta premisa necesaria -la acción- para que el poeta sienta que pertenece al mundo, indudablemente tiene que ver con un proceso de rebelión interna, que va elevando el tono a medida que el libro crece en poemas, y en el que la figura del Poeta comienza a erigirse con un papel principal. Poeta, ya lo he advertido, de hechura romántica, con evidentes connotaciones épicas y prometeicas; imagen también de la diferencia que salva de la vulgaridad del mundo. Cernuda empieza a poner así la primera piedra de lo que con el tiempo terminará por convertirse en una mitificación de esa figura del Poeta, dentro de la concepción de la obra como autobiografía espiritual ${ }^{19}$. Es cierto que esa construcción autobiográfica habrá de cargar inexorablemente con el peso de una leyenda (mejor, de una doble leyenda: la mítica consolidación de la construcción romántica del Poeta, y también la ajena, que tanto dolerá al hiperestésico L uis Cernuda a lo largo de sus días). Pero toda escritura es, al cabo, leyenda y la poesía rehuye, con razón, la crónica, aunque no renuncie al testimonio. Cernuda inicia, en fin, su andadura vital en este libro y va aprendiendo a conocerse, a descifrar su mundo interior, en permanente lucha entre la realidad que le cerca y el deseo que le tienta y proyecta; pero también aprende a perfilar de manera clara una identidad que convertirá muy pronto en bandera defensiva, en una manera, rebelde y solitaria, de estar, aunque no exactamente de pertenecer al mundo. Un universo, en suma, que va fraguando en una iconografía de signo fetichista, como ocurre con "Durango" y sus guerreros, donde la épica soñada vuelve a quedar, como en los poemas anteriores, sin resolver, bajo la conciencia, tan temida, de la esterilidad.

Las palabras quisieran expresar a los guerreros,

B ellos guerreros impasibles,

Con el mañana gris abrazado, como un amante,

Sin dejarles partir hacia las olas.

(...)

Durango está vacío

Al pie de tanto miedo infranqueable;

L lora consigo a sol as la juventud sangrienta

De los guerreros bellos como luz, como espuma. (R. y D. Pág. 97)

19. "Así La realidad y el deseo puede verse como una autobiografía espiritual, sucesión de momentos vividos y reflexión sobre esas experiencias vitales. De ahí su carácter moral". Escribe Octavio Paz en "La palabra edificante", en Luis Cernuda, opus cit., pág. 140. 
Es el poeta, la incipiente cimentación del mito del Poeta ${ }^{20}$, habitado por un daimon, quien teme habitar un territorio yermo que termine inutilizando también a la palabra que tanto necesita, ya casi convertida en razón fatal del existir y, por tanto, de la necesaria identidad: es el primer verso el que busca la tautología de la palabra poética con la evocación deseada, las palabras igualando a la expresión poética de los guerreros. No ha dejado, por tanto, Cernuda de proyectar sus sueños y deseos en idealizaciones ingrávidas, paradisíacas como sugerencia de una búsqueda de la luz verdadera, aquello que no engaña en medio de los señuelos que interpone una realidad que el poeta cruza entorpecido. "Daytona" se enmarca también en los poemas que podemos denominar como miradas después de la inocencia, pero donde ya propone otra necesidad más imperiosa: el amor. El poeta sabe de un mundo lejano en el que "la luz no engañaba", donde las manos "tristes no sostenían un cuervo", y, como en "El caso del pájaro asesinado", aquí también se "ha cortado la piedra en flor", pero Daytona está ahí, mítica imagen del deseo, sonriendo "hacia el amor". El poeta mira de la misma manera en sus sueños, deseando la luz fértil del sueño del amor. El deseo del poeta se contempla en el espejo de "Daytona".

Que a partir de estos poemas, Cernuda ha aprendido mucho de sí mismo es un hecho evidente, porque juzga ya su indolencia adolescente, el sueño hipnótico de su claustro narcisista, como un entumecimiento del ser, que acusa como impotencia la fragilidad de su mismo desear. A sí también, tras la impotencia y la dificultad de encontrar el calor humano, asistimos, como un golpe brusco, al desencadenarse del Ilanto, un Ilanto que suel ta como un lastre el peso de la angustia y que evidentemente cumple una función catártica. Reconoce, como escribe en "Desdicha", que los brazos son nubes y que no tienen la fuerza del viento para estrechar otros brazos. Le hace falta el impulso definitivo de la pasión romántica que le aleje del desengaño y de la cerrada atmósfera de entresoñado laberinto de espejos en el que se mueve como un pájaro enjaulado, sintiéndose ya un ángel caído. Los brazos son ahora más importantes que las alas, y las palabras también

20. Cernuda siempre buscó explicaciones mitológicas a su soledad, a su terrible aislamiento, pues necesitaba dar respuesta poética a las incógnitas de su vida. Si en este libro va cobrando forma la mitificación de la figura del Poeta en clave prometeica, más adelante, cuando se cumpla de manera fatal su expulsión de la tierra como destierro, tras la Guerra Civil, Cernuda cifrará el vencimiento del Poeta en una relectura del mito de M arsias. Su poesía es un desafío que levanta ante los dioses desde su humanidad, y ello significa siempre castigo. M arsias representa para Cernuda otra encarnación del Poeta romántico, que canta una aspiración órfica de absoluto. Cernuda se quedará, pues, a solas con su poesía, y recreará la prehistoria de todo su mundo en 0 cnos. El verso de Garcilaso "B rotó una melodía doliente y pura / con temblor oscuro" evoca de manera clara la aspiración poética de Cernuda como un nuevo M arsias. 
deben abrirse a esa nueva fuerza que ya sabemos que se llamará rebeldía, aunque todavía ignore cómo:

Pero él con sus labios,

Con sus labios no sabe sino decir palabras;

Palabras hacia el techo,

Palabras hacia el suelo,

Y sus brazos son nubes que transforman la vida

En aire navegable. (R. y D. Pág. 99)

\section{V $\mathbf{I}$}

Quizá esa es la razón, la rebeldía, de que el mundo simbólico del fuego, también como elemento primordial, empiece a desdoblar sus asociaciones, se abra paso entre el imaginario del agua y el aire. Porque si antes las imprecisas imágenes del fuego quedaban asociadas a una transposición de las vagas luces del sueño (la luz, en efecto, es una prefiguración del fuego), calentando apenas, ahora los poemas incorporan colores rojizos, en una pal eta que oscila entre escarlatas muy densos y las luces abiertamente rojas que proyecta, anunciando el peligro en medio de la noche, una "Linterna roja". El libro continúa desenvolviéndose en un contexto nocturno, pero las tonalidades grises ceden su espacio a ráfagas rojizas, aunque no notemos aún su acción calorífica. El efecto cromático del rojo configura otro paso adelante en el ritual iniciático del libro, pues es incontestable que podemos asociarlo al desatarse de la pasión, al irrefrenable ardor del deseo que busca dar forma carnal a unas proyecciones que aún se mueven en un universo de signo narcisista, aunque el poeta pretenda escapar de su trampa estéril.

Sale, pues, el protagonista de U n Río, un Amor, en busca del amor, un nuevo dios que pueble sus días, y que, como escribí, se anuda a una concepción romántica de la libertad. En "No intentemos el amor nunca", el protagonista se ve impulsado por esa paradoja del amor que más tarde formulará como una libertad que únicamente se comprende estando preso en alguien ${ }^{21}$. Pues bien, en este poema, el mar, icono de libertad romántica, se transforma en una proyección de la voz el poeta nocturno, rebelde, aunque rememore su reciente conocimiento de la caída en esas imágenes de "astros caídos " 0 en "las manos de tierra":

21. "Libertad no conozco sino la libertad de estar preso en al guien / Cuyo nombre no puedo oír sin escal ofrío, / Alguien por quien me olvido de esta existencia mezquina, / Y mi cuerpo y espíritu flotan en su cuerpo y espíritu / Como leños perdidos que el mar anega o levanta / Libremente, con la libertad del amor, / L a única libertad que me exalta, / L a única libertad porque muero." (R. y D. Pág. 125), escribe en Los placeres prohibidos, su libro siguiente. 
Cantaba tempestades, estruendos desbocados

Bajo cielos con sombra,

Como la sombra misma,

Como la sombra siempre,

Rencorosa de pájaros estrellas.

(...)

M as el mar se cansaba de esperar las ciudades.

Allí su amor tan sólo era un pretexto vago

Con sonrisa de antaño

Ignorado por todos.

Y con sueño se volvió lentamente

A donde nadie

Sabe nada de nadie,

A donde acaba el mundo. (R y D. Pág. 100)

Es la soledad, en efecto, trágico estigma del hombre que deja atrás su inocencia, aquel sueño de un inventado paraíso. Soledad que habrá de convertir en compañera, aunque ahora el poeta busque con desesperación la comunicación, el calor, el cobijo de un cuerpo humano, en un mundo extraño que le hostiga dándole la espalda, y cuya visión poética continúa vertiéndose en gélidas imágenes de desamparo. En su vagabundeo nocturno, sin embargo, halla, seres igualmente derrotados, y se identifica con su vencimiento: son esos mendigos que retrata con imágenes magníficas en "Linterna roja", Ios "reyes sin corona" que, como él, "buscaron deseos terminados en nubes", pero finalmente su soledad inmensa, desbordada de deseo, le devolverá al Ilanto. Queda así perfilado, de manera gráfica, el poeta como una figura en pose estudiadamente romántica, casi diría que tópica malgré lui, y a pesar, o tal vez por eso mismo, del arnés superrealista: un joven melancólico, vuelta la espalda al mundo, caídas las alas que se vuelven, sin embargo, implorantes hacia la única salida que le queda al narcisismo adolescente, la apasionada erótica entre iguales, si bien todavía imprecisa en su manifestación, apuntada en la imagen de la lámpara que ilumina el deseo, que alumbra en medio de la oscuridad del mundo. Hay, en todo caso, una atmósfera que ya anuncia el paisaje de Donde habite el olvido, y que recuerda el misterio de algunas composiciones de Friedrich, también la luz crepuscular de Turner y el indomesticable oleaje que pinta en sus mejores marinas ${ }^{22}$.

22. Sobre el paisajismo romántico escribe R. Argullol: "Los dos mayores paisajistas del Romanticismo, Caspar David Friedrich y William Turner, recurren al enfrentamiento hombre-mar con harta frecuencia", y analiza la naturaleza, el universo apocalíptico "anterior y posterior a los 
A todo ello hay que añadir la aparición de una simbología que va cobrando una muy definida caracterización erótica, donde, como ya he dicho, se asienta la afirmación de una clara definición homosexual, pero a caballo todavía entre la idealización de la pureza y el terrible azote de la pasión y la carne. Podemos entender así que los mares se hayan teñido de un color escarlata, aunque el poeta se sepa encerrado en su triste "gemido molusco", y nos hable de la "Razón de las lágrimas", pero los mármoles ahora están encendidos, y las columnas son lascivas para ese manto, para ese pecho escarlata. La luz ensoñada ha ido cediendo, efectivamente, su espacio natural al simbolismo del fuego, porque la pasión se enseñorea incontenible en este momento clave de iniciación a la vida. L as imágenes derivadas del simbolismo del fuego, bien sea en la evocación de los colores rojizos 0 en la clara voluntad de hacer evidente la pasión, incendiando tristezas 0 mares de deseo, dan cuenta de esa transformación iniciática: el fuego es otra manera de entender el universo de la luz que ahora se puebla con un significado más hondo, porque el fuego también tiene una clara connotación catártica, como las explícitas lágrimas vertidas: a través de su efecto el poeta abandona lentamente el mundo de sombras, sale al encuentro del ardor de las formas, aunque todavía le habiten momentos de cansancio y recaída, y sepa también de la difícil cura de su soledad.

La apertura del poeta hacia el amor invita a abundar en la cuestión decisiva del narcisismo cernudiano, pues hay que señal ar que dentro de lo que he denominado como erótica entre iguales, la búsqueda del protagonista de U n Río, un Amor no fija la mirada únicamente en el otro como espejo reconocible, sino como punto de fuga hacia el olvido: olvido de sí mismo en otro olvido, puerta de salida del infierno solitario y frío de uno mismo. El encuentro del otro es un despertar, luz o fuego, tras la noche del al ma oscura, que abre la pasión del cuerpo; liberación, por tanto, de ahí el retorno de los ámbitos soñados como posibles, el regreso de imágenes idealizadas tan evidentes en su configuración neoplatónica de signo órfico, como la noche deslumbrante de "Razón de las lágrimas" o la recurrencia a la imagen de las estrellas en "Todo esto por amor". A hora bien, el escenario nocturno pone en evidencia que ese universo idealizado tienta en atmósferas callejeras, porque la noche, como una prostituta, "retuerce sus caderas" junto a las esquinas, y los "labios que dan otras estrellas" están envuel tos en "brumas escarlata". Cernuda despierta de su sueño, mientras un ímpetu huracanado le lleva a afirmar

hombres" de algunos cuadros de estos pintores, sin olvidar la proyección de un mar pacífico como plenitud "se hace inasequible". 0 pus cit. Págs. 315-316. La simbología marítima en estos poemas configura asociaciones semejantes. 
que no importa que derriben "imperios de un beso" "monarquías de un beso" si puede avistar la forma de su amor en unos ojos. A sí es como nace la búsqueda de un nombre que acoja la realidad presentida, y seguramente tan cercana, remarcada en la presencia del demostrativo "estos ojos", como podemos apreciar en los versos de "Todo esto por amor":

\author{
M as este amor cerrado por ver solo su forma, \\ Su forma entre brumas escarlata, \\ Quiere imponer la vida, como otoño ascendiendo tantas hojas \\ Hacia el último cielo, \\ Donde estrellas \\ Sus labios dan a otras estrellas. \\ Donde mis ojos, estos ojos, \\ Se despierten en otros. (R. Y D. Pág. 104)
}

L a voz se ha reafirmado notablemente a estas alturas del libro, de la misma forma que ha ido creciendo el movimiento del deseo tras la idea del amor materializada en un cuerpo, de manera que empiezan a darse cita en los versos formas humanas, entrevistas 0 ensoñadas: fetiches, es cierto, de una belleza ideal, a menudo bordeando la imaginería angélica, que alcanzarán su plenitud en Los placeres prohibidos ${ }^{23}$, su libro siguiente, donde la afirmación identitaria es ya una fuerza de rebelión que ha tomado posesión del mundo del deseo. Pero de momento el poeta no sabe qué nombre darle a esa forma presentida en sueños, como anuncia el título de un poema: esa imagen del amor, evocado desde un fondo luminoso donde parece preexistir la libertad redentora. El amor sin nombre es, como la Psique curiosa de A puleyo o las vírgenes vigías del Evangelio, portador de una lámpara, que alumbra la verdad el mundo. Capaz de al ejar las sombras, el amor promete abandonar el doloroso subterráneo de fantasmas, disolver la angustia, romper las cadenas, huir del "mundo esclavizado":

La vida puso entonces una lámpara

Sobre los muros sangrientos;

El día ya cansado secaba tristemente

23. No podemos afirmar que por las fechas en que compone estos poemas, Cernuda tenga ya un amante, sin embargo, la lectura entre líneas de los poemas parece sugerir que ha encontrado el cuerpo, la añorada forma que persiguen los versos. Sabemos, no obstante, que L orca le presentó a Serafín Fernández Ferro, que sería el destinatario de los dolorosos poemas de D onde habite el olvido, una vez desengañado el poeta de que su universo de proyección platónica, habitado por un dios hecho a su imagen y medida, no se correspondía con la realidad. V éase sobre esta cuestión y la posible relación de L orca y Cernuda, el capítulo "Los amantes descarriados" de Acelerado sueño. 
L as futuras auroras, remendadas

Como harapos de rey.

La lámpara eras tú,

M is labios, mi sonrisa,

Forma que hallan mis manos en todo lo que alcanzan.

(R. Y D. Pág. 105)

\section{VII}

Si para Keats, a quien aludirá, identificándose, en un poema de madurez, la belleza es verdad, en el universo cernudiano esa verdad del amor en la belleza es también luz liberadora, despertar acaso. Sin embargo, tras estos exaltados poemas, tan cercanos ya a Los placeres prohibidos, Cernuda volverá a descender al mundo introspectivo, en una teatralización dramática de su estado, pues reconoce que el paisaje alucinatorio que ha ido dibujando está dentro de él, ratificando de nuevo la soledad y el miedo, la inseguridad ante la salida de su estado de postración, al que todavía se siente indefectiblemente abocado. Poemas como "D rama o puerta cerrada" o "D ejadme solo", en los que el poeta se cuestiona a sí mismo, poniendo sobre el tablero la dimensión de su fuerza, el oscuro combate que libran la realidad y el deseo, funcionan como un recuento de las vivencias pasadas bajo la perspectiva de una mirada que reflexiona o interroga a aquello que ya fue pero también al inmediato futuro. Crónica también de la caída donde el poeta ha conocido la presencia de la muerte:

La juventud sin escolta de nubes,

Los muros, voluntad de tempestades,

La lámpara, como abanico fuera o dentro,

Dicen con elocuencia aquello ignorado

A quello que algún día débilmente

A nte la muerte misma se abandona. (R. y D. Pág. 107)

Pero estos poemas, no del todo ajenos a una impronta psicoanalítica, se alternan con intermitentes imágenes de idealización, "Carne de mar" es un claro ejemplo porque regresa la añoranza de otros mundos, apenas delineados, como si Cernuda trabajase sus espacios poéticos a la acuarela, y que contrastan con la dureza de la propia vida delimitada en esa terrible "piel de naufragio" de la que tan difícil le es escapar. Virginia y sus cazadores, como antes Nevada, Daytona 0 los guerreros de Durango, representan un mundo virtual de inspiración fetichista, 
brumoso por lo lejano, evocador en sus nombres, que pasan frente a él como añoranzas o vagos anhelos que quisiera alcanzar, sumergirse en su atmósfera de ensueño, quizá penetrando esa pantalla tan semejante al universo cinematográfico, para hallar allí la representación quizá del afán que sueña su deseo:

\author{
Sí, los cuerpos estrechamente enlazados, \\ Los labios en la llave más íntima, \\ ¿Qué dirá él, hecho piel de naufragio \\ 0 dolor con la puerta cerrada, \\ Dolor frente a dolor, \\ Sin esperar amor tampoco? ( R. y D. Pág. 109)
}

El amor ensoñado, en efecto, como teme el poeta, puede pasar ante él sin dar limosna a "nubes mutiladas", puede no detenerse, ignorarlo. Cernuda va comprendiendo y midiendo así las hechuras del mundo real, de ese mundo cuya puerta va franqueando con una mezcla de impaciencia, recelo y un terror muy humano. También sabe que el tiempo no vuelve atrás, como tampoco puede regresar el que fue, y por esa razón, este hombre joven trata desesperadamente de liberarse de las sombras de la caverna sin poder complacerse demasiado en la contemplación de lo que ya ha sido, aunque su impotencia o los restos de indolencia adolescente, cándida y narcisista, todavía mantengan una presencia activa en los poemas, aun a sabiendas de que se trata de un mundo caído. A sí la divisa de Cernuda, a pesar de la mirada que se posa en la rememoración simbólica del pasado, como en "Vieja ribera", es ya una postura que evidencia la rebel día declarada que pone definitivamente fin al antiguo lecho de adormideras. Cernuda declara ya intenciones frente a las "tumbas de estrellas apagadas". R eafirma la pasión incluso en la derrota y acepta abiertamente el mundo nocturno - uraniano, dionisiaco- de la carne, reino de Eros, entronización de Pandémica. Los últimos poemas del libro abren la brecha de un grito casi subversivo poblado de imaginería erótica, pues fluctúan entre la niñez del sueño que ha quedado atrás y el mundo que ahora se extiende, como una tentación, ante el poeta. "L a canción del oeste" convoca todavía a los viejos fetiches de la luz, a la canción de antaño, pero el fuego purificador ha convertido en hoguera aquellos mundos antiguos. El poeta se sabe hombre con su estigma de hombre, por eso:

Olvidemos pues todo, incluso el mismo oeste;

Olvidemos que un día las miradas de ahora

L ucirán a la noche, como tantos amantes,

Sobre el lejano oeste,

Sobre el amor más lejano. (R. Y D. Pág. 111) 
Cernuda, o mejor, el Poeta que comienza, aun de manera imprecisa, su entronización en este libro, ha conquistado en el transcurrir del libro su carta de naturaleza, ha decidido ingresar en el mundo, cumplido el ritual de iniciación; y este novicio de rara heterodoxia que al fin vislumbramos, lo hace desde el grito, derribando mundos falsos, destruyendo el engaño y la falsificación de cuanto ha visto, escapando de un universo poblado de fantasmas, cortando los lazos hipnóticos del sueño adolescente, aferrado ahora al descubrimiento de la carne, encarnado en la imagen del solicitante. Por ello se plantea todavía con una interrogativa que tiene poco de retórica si ciertamente "¿Son todos felices?": es evidente que la felicidad burguesa para Cernuda resulta incompatible con la vida verdadera que ha descubierto dentro de sí, no cabe en su mirada la hipocresía tartufa pues ha aprendido que vivir es derrota, y así la exalta, anunciando ya la agitada bandera que habrá de ondear muy pronto en sus versos:
A bajo pues la virtud, el orden, la miseria;
A bajo todo, todo, excepto la derrota,
Derrota hasta los dientes, hasta ese espacio helado
De una cabeza abierta en dos a través de soledades,
Sabiendo nada más que vivir es estar a solas con la muerte.
(R. y D. Pág. 112)

Desde esta soledad lacerante y desde el conocimiento de la realidad del mundo, el poeta busca al otro que le identifique definitivamente, que le obligue a salir del laberíntico juego de espejos, para abrir "las puertas del olvido labio a labio", como escribe en "N octurno entre las musarañas". El amor se adelanta, surgiendo del agua, emergiendo en medio de la corriente del río, como cifra de un nuevo paraíso, en el que el poeta buscará una nueva percepción de la luz. El último poema de Un Río, un Amor, supone el intento final de huir de las trampas que le ha tendido Hipnos a lo largo de su dilatada adolescencia, de escapar de los espejos de roca que le han mantenido atrapado en una pura visión narcisista y quieta, y que ahora le ahogan irremediablemente, cercándole todavía con sus lianas de angustia. "Como la piel" no oculta el descubrimiento de los otros placeres, que intuimos prohibidos, y en los que ahora entra con pie decidido:

Esas cuevas de luces venenosas

Destrozan los deseos, los durmientes;

Luces como lenguas hendidas

Penetrando en los huesos para hallar la carne,

Sin saber que en el fondo no hay fondo,

No hay nada, sino grito,

Un grito, otro deseo

Sobre una trampa de adormideras crueles. 
En un mundo de alambre

Donde el olvido vuela por debajo del suelo.

En un mundo de angustia,

Alcohol amarillento,

Plumas de fiebre,

Irá subiendo a un cielo de vergüenza,

A Igún día nuevamente resurgirá la flecha

Que abandona el azar

Cuando una estrella muere como otoño para olvidar su

sombra. (R y D. Pág. 114)

L a suerte está echada: para el poeta L uis Cernuda comienza otra aventura tras cruzar el umbral que cierra, o abre, el último poema de Un Río, un Amor, y lo hará, fatalmente, bajo el signo de la rebelión y la desdicha, tratando de conquistar esa realidad presentida que sueña con tantísima intensidad su amoroso deseo. 